\title{
EPISTEMOLOGI TAFSIR SUFI PERSPEKTIF ESOTERIK-FENOMENOLOGI
}

\author{
D.I Ansusa Putra
}

UIN Sulthan Thaha Saifuddin Jambi

E-mail: ansusa@uinjambi.ac.id

\begin{abstract}
This paper is a comprehensive study of sufi epistemology through interpretations of natural phenomena. The study of the triagle causality relationship between God, humans, and nature can be a binocular for studying the sufistic epistemology globally. In sufistic studies, studying natural phenomena is one way to reach the essence of God. Whereas the existence of God can be studied through His signs. This paper uses an approach from a theological scholar, Patrick Masterson, who concusively found a new approach that accommodates esoteric and exoteric dimensions simultaneously. The author considers this approach feasible to use to understand the sufistic epistemology, especially those related to natural phenomena.
\end{abstract}

Tulisan ini merupakan kajian komprehensif mengenai epistemologi sufi melalui penafsiran-penafsiran fenomena alam. Kajian hubungan kausalitas segitiga antara Tuhan, manusia, dan alam dapat menjadi teropong untuk mengkaji epistemologi sufistik secara global. Dalam kajian sufistik, mengkaji fenomena alam merupakan salah satu jalan untuk mencapai esensi Tuhan. Sedangkan keberadaan Tuhan dapat dikaji melalui tandatanda-Nya. Tulisan ini menggunakan sebuah pendekatan dari seorang sarjana teologi bernama Patrick Masterson yang secara meyakinkan telah menemukan sebuah pendekatan baru yang mengakomodir dimensi esoterik dan eksoterik secara bersamaan. Penulis menilai pendekatan ini layak 
digunakan untuk memahami epistemologi sufistik, khususnya yang berkaitan dengan fenomena alam.

Keywords: esoteric-phenomenology approach; sufi interpretation; verses of phenomena

Received: June 28, 2018; Accepted: November 14, 2018

\section{Pendahuluan}

Seringkali masyarakat akademik sulit memahami epistemologi sufi berkaitan dengan hubungan manusia, alam, dan Tuhan. Sebagaimana diketahui bahwa paradigma intuitif sufi merupakan paradigma yang bersifat internal dan sangat pribadi, sehingga perlu sebuah pembacaan yang radikal terhadap alur pikir hasil penafsiran sufi. Epistemologi tafsir sufi masih perlu dielaborasi karena hanya beberapa pakar saja yang mau meneliti dan mengungkap metodologi tafsir sufi. Kebanyakan para peneliti terhenti pada aspek corak dan hasil penafsiran sufi (Sands 2006, 2). Padahal, secara empiris, Tuhan dan fenomena alam adalah dua realitas yang saling berlawanan. Namun, tokoh-tokoh sufi seperti Ibn 'Arabî, al-Rûmî, alGhazâlî, dan lain-lain berhasil mempertemukan keduanya dalam berbagai pembacaan dan penafsiran (Al-Attas 2005, 33). Meski begitu, masyarakat akademik seringkali sulit memahami epistemologi sufistik untuk membedah pembacaan sufi terhadap dua realitas tersebut. Hal itu dikarenakan pembacaan sufistik yang bersifat batin dan intuitif.

Terbatasnya pengkajian epistemologi tafsir sufi juga berdampak terhadap terbatasnya pemahaman kajian tentang perspektif sufi dalam memandang dunia dan segala fenomenanya. Padahal, dalam tafsir sufi ditemukan banyak komentar terkait Tuhan dan makhluk-Nya. Bahkan, telah lahir banyak istilah-istilah sufi khusus yang menggambarkan hubungan antara Tuhan dan makhluk-Nya. Contohnya, dalam kitab Mathnawî Ma'nawî karya Jalâl al-Dîn al-Rûmî digambarkan mengenai relasi Tuhan dengan 'penanda Tuhan' yang diwakili oleh makhluk. Al-Rûmî mengatakan: "Wa fî kulli shay'in lahî shahîd, yadullu 'alâ annahû wahîd (Dan di setiap segala sesuatu adalah saksi, yang menunjukkan bahwa Dia adalah satu) (Schimmel 1994, 15)

Dapat dipahami bahwa sulitnya memahami epistemologi sufi dan tafsir sufi disebabkan oleh belum finalnya metode 'irfânî dalam bangunan keilmuan positivisme-empirik. Tulisan ini bertujuan untuk mencoba 
menemukan titik temu antara epistemologi sufi dalam bangunan kajian ilmiah melalui penafsiran ayat-ayat kawniyah. Kajian ilmiah yang dimaksud dalam tulisan ini adalah esoterik-fenomenologi. Esoterik-fenomenologi di sini menggunakan pendekatan Masterson dalam karyanya Approaching God Between Phenomenology and Theology. Masterson menjelaskan fenomena Tuhan dari tiga perspektif, yaitu fenomenologis, metafisik, dan teologis (Masterson, 2013, 69).

Penulis menilai bahwa mengkaji hubungan Tuhan, manusia, dan alam merupakan kacamata yang sesuai untuk mengetahui pembacaan dan epistemologi sufi. Karena, paradigma sufistik merupakan paradigma yang terpusat pada cara untuk mencapai kebenaran Tuhan. Kebenaran akan Tuhan selalu melibatkan alam dan manusia sebagai ciptaan-Nya, setidaknya dalam pendekatan esoterik-fenomenologi. Mudah-mudahan tulisan ini akan membantu masyarakat akademik dalam memahami epistemologi sufi secara global. Penulis juga berkeyakinan bahwa mengkaji epistemologi sufistik secara parsial akan berakibat pada lemahnya kesimpulan dan hipotesis, seperti beberapa tulisan sarjana yang mencoba menjelaskan epistemologi sufistik di bawah ini.

Kebanyakan pengkaji tafsir menjelaskan epistemologi tafsir sufi dari kacamata tiga bentuk kategori keilmuan Islam (bayânî, burhânî, dan 'irfânî). Padahal ketegori keilmuan yang dipopulerkan oleh al-Nasafî ini tidak bisa serta merta dijadikan pisau analisis untuk menerangkan epistemologi tafsir sufi, sebab memang al-Nasafî merumuskannya dalam konteks keilmuan Islam yang global. Menurut penulis, kategorisasi ini memberikan masalah yang serius karena penafsiran sufi selalu dikategorikan sebagai ilmu yang given/mawhibah dan non-ilmiah, sebagaimana yang dipahami oleh Muhammad Husayn al-Dhahabî (al-Dhahabî 2004, 96). Kategori tafsir sufi melalui kategori keilmuan Islam ini menjadi sangat populer dengan dirumuskannya epistemologi Islam ala Muhammad 'Âbid al-Jâbirî (al-Jâbirî 2009).

Tulisan pakar Alquran dengan cara ini mendominasi penilaian terhadap epistemologi sufi dewasa ini. Hampir seluruh tulisan yang berkaitan dengan epistemologi tafsir sufi menyertakan kategorisasi keilmuan Islam yang disebutkan sebelumnya. Beberapa karya dengan tipe seperti ini dapat disebutkan sebagai berikut:

Pertama, Cristin Zahra Sands dalam buku Sufi Commentaries on The Quran in Classical Islam. Cristin Zahra Sands dikenal sebagai pengkaji 
Alquran yang memulai studi tafsir sufinya dengan mengkaji penafsiran alTustarî. Sands bersama Gerhard Bowering membagi fase perkembangan tafsir sufi dari masa ke masa. Walaupun tidak secara rinci mengkaji epistemologi tafsir sufi, namun Sands juga melihat tafsir sufi sebagai penafsiran intuitif-fiktif (Sands 2006).

Kedua, tulisan Syaifan Nur yang berjudul Epistemologi Sufi dan Tanggung Jawab Ilmiah. Dalam tulisan ini, Syaifan Nur mencoba meletakkan epistemologi sufi dalam bagian kajian ilmiah, akan tetapi pendekatan yang digunakan dalam usahanya tersebut masih sebatas pendekatan 'irfânî, sehingga solusi yang ditawarkan masih bersifat apologetis. Syaifan masih membedah epistemologi sufistik yang bertitik tolak dari tiga bentuk epistemologi Islam, yakni bayânî, burhânî, dan 'irfânî. Padahal, titik tolak ini hanya akan medorong penilaian ke ranah dikotomi keilmuan. Selanjutnya, Syaifan dalam tulisannya seringkali menyalahkan paradigma positivismeempirik sebagai biang ketidakpopuleran epistemologi sufistik. Sikap-sikap skeptis ini hanya akan menjauhkan dari hakikat ilmu. Karena dalam Islam tidak ada ilmu yang tidak benar, hanya saja keberadaan ilmu seringkali disalahgunakan (Nur 2012).

Ketiga, tulisan Syamsuddin Arif berjudul Sufi Epistemology: Ibn Arabi on Knowladge yang memaparkan epistemologi sufi melalui definisi Ibn 'Arabî mengenai ilmu. Kemudian, Syamsuddin mengomparasikan pendapat Ibn 'Arabî mengenai definisi ilmu dengan tokoh-tokoh sufi terkemuka seperti al-Ghazâlî, al-Jurjânî, dan lain-lain. Kajian ini, menurut penulis, tidak komprehensif dalam menguak epistemologi sufistik. Hal ini dikarenakan tidak semua tokoh sufi menjadikan ilmu sebagai pusat aspek batiniyahnya. Artinya, kajian ini tidak mewakili semua epistemologi sufi dan hanya mewakili epistemologi sufistik dengan 'mazhab' ilmu saja, seperti Ibn 'Arabî, al-Ghazâlî, dan al-Jurjânî. Sedangkan epistemologi sufi dengan pendekatan lain tidak tersentuh, seperti al-Rûmî, al-Hallâj, Râbi'at al'Adawiyah, dan lain sebagainya (Arif 2002).

Keempat, tulisan Mustafa Mahmoud Abu-Sway berjudul The Development in al-Ghazali's Epistemology. Tulisan ini pada hakikatnya sama dengan tulisan Syamsuddin Arif, yakni tidak dapat merepresentasikan epistemologi sufistik secara komprehensif. Sebagaimana diketahui, alGhazâlî merupakan tokoh sufi yang cenderung menggunakan ma'rifah sebagai cara untuk mencapai kebenaran Tuhan, sehingga dapat dikatakan 
masih satu aliran dengan 'mazhab' Ibn 'Arabî sebagaimana yang telah dijelaskan sebelumnya (Abu-Sway 1994).

Barangkali tulisan yang menawarkan pola tasawuf-religius eksperimen dari al-Ghazali seperti apa yang dijelaskan Iqbal. Iqbal menilai Pengalaman ghaibiyat (pengalaman mistik) yang berupa ilham akan mengkristalkan keyakinannya untuk tetap berpegang kepada pendiriannya tentang keterbatasan rasio dan penginderaan sehingga ia mencari garis pemisah antara pengetahuan empirik dan rasio dengan pengalaman mistik (Sir Muhammad Iqbal, 1934: 7)

Selain empat karya di atas, terdapat karya-karya lain seperti Waryani Fajar Riyanto yang menjelaskan tentang paham anti sinonim dalam tafsir sufi kontemporer (Riyanto 2014); M. Anwar Syarifuddin yang mengulas tentang otoritas sufi dalam menafsirkan teks Alquran (Syarifuddin 2004); Badruzzaman M. Yunus yang mengulas pendekatan sufi dalam menafsirkan Alquran (Yunus 2017); dan Kholid Al-Walid yang mengkaji takwil Ibn 'Arabî pada surah al-Nûr ayat 35 (Al-Walid 2018). Dengan demikian, tulisan ini menemukan letak perbedaan dengan kajian-kajian lainnya tentang tafsir sufi sebagaimana diulas sebelumnya.

\section{Kebuntuan Memahami Epistemologi Tafsir Sufi}

Pembicaraan tentang epistemologi sepanjang sejarah merupakan sesuatu hal yang penting bagi para pengkaji untuk bisa menembus 'substansi' atau 'realitas' sesuatu. Mendiskusikan epistemologi sufi dapat dilacak melalui ketidaksetujuan para sufi terhadap banyak statemen para filsuf, teolog (mutakallimûn) dan juga ahli hukum (fuqahâ') yang cenderung mengabaikan sisi esoteris dalam pengetahuan Islam (Chittick 1989, 147) Menurut sufi, pendekatan intuitif terhadap pengetahuan pada dasarnya tidak bertentangan dengan rasionalisme dan empirisme bahkan mendukung keduanya. Beberapa tokoh sufi membuat formulasi epistemologi sufi dan melahirkan banyak istilah tentang epistemologi sufi. Seperti tulisan-tulisan Ibn 'Arabî yang memusatkan perhatiannya pada istilah teknis seperti 'pembukaan spiritual' (fath), pembukaan (kashf), dan merasakan (dhawq). Ibn 'Arabî juga membahas klasifikasi pengetahuan dan juga berbagai cara untuk mengakuisisinya.

Memahami formulasi pengetahuan dari sudut pandang sufi merupakan pekerjaan yang membutuhkan fokus dan konsentrasi. Berkaca pada kemajuan kaidah penafsiran esoterik (zâhir), pembacaan metodis dalam studi tafsir esoterik (tafsir ishârî/sûfî/bâtin) menjadi permasalahan 
tersendiri dengan polemik yang meruncing pada kaidah penafsiran. Hal ini disebabkan oleh beberapa faktor: pertama, para pencetus awal mufasir sufi tidak memberikan pembatasan yang detail tentang kaidah penafsiran sufi serta hanya pembatasan yang bersifat menghakimi tafsir dalam kategori mahmûd/maqbôul, terpuji/diterima dan madhmûm/mardûd, buruk/ditolak. Penjelasan kaidah tafsir sufi ini relatif tidak aplikatif dan cenderung dalam area yang sulit dijangkau. Tidak heran jika tafsir esoterik atau tafsir sufi diidentikan dengan tafsir eksklusif, hanya dapat dijangkau sebagian kecil komunitas mufasir.

Kedua, terjadinya eksklusifitas tafsir yang mengakibatkan kemandekan pertumbuhan metodologi tafsir sufi. Hal ini dibuktikan dengan pembatasan yang secara tajam dijelaskan al-Ghazâlî (w. 505 H/1111 M) dengan menegaskan pembatasan otoritas penafsiran. Al-Ghazâlî menyimpulkan bahwa makna esoterik Alquran hanya dapat diakses oleh pemilik jiwa yang suci (al-qulûb al-zâkiyyah), yakni para sufi yang memperoleh ketersingkapan pengetahuan (mawhîb), bukan sekedar makna-makna lahiriah. Al-Ghazâlî menggarisbawahi bahwa otoritas penafsiran sufi dibatasi hanya pada orang-orang khusus, yaitu para sufi yang mendapatkan pengetahuan mukâshafah (Treiger 2002, 29). Makna esoterik diklaim para sufi sebagai ilmu khusus yang diberikan Allah kepada mereka secara transenden. Ini artinya, tafsir sufi bersifat eksklusif disebabkan oleh faktor ketersingkapan makna esoterik yang menurut para sufi mempunyai spektrum makna yang lebih dalam isi dan cakupannya ketimbang makna eksoteriknya.

Ketiga, sangat sulit untuk memahami epistemologi tafsir sufi disebabkan menyangkut kerangka fikir yang bersifat intuitif. Epistemologi tafsir sufi mencakup pengalaman religius (religious experiences) sebagai sumber pengetahuan dalam menyelami dan menyingkap makna batin dalam ayat-ayat Alquran. Pengetahuan batin yang berasal dari sumber seperti itu dikenal dengan nama 'Ilm al-Bâtin (Sands 2006, 30). Definisi ini termasuk dalam kategori ilmu menurut al-Nasafî. Dalam konteks ini, alNasafî mengategorikan ilmu menjadi tiga kategori, yaitu panca indera, kabar yang benar, dan akal, ditambah dengan ilmu melalui intuitif/ilham (Rosenthal 1970, 96-97). Namun, kategori al-Nasafî tentang ilmu tidak dibarengi dengan metode untuk mencapai pengetahuan intuitif. Keempat sumber ilmu menurut al-Nasafî (panca indera, akal, khabar sâadiq, dan 
intuisi) adalah sumber ilmu yang dilihat dari sisi epistemologis, yaitu alat/saluran/instrumen untuk memperoleh ilmu pengetahuan.

Kesulitan untuk memahami epitemologi tafsir sufi semakin diperparah dengan fakta bahwa tidak ada definisi tunggal pengetahuan yang pernah disepakati oleh para ilmuwan. Al-Jurjânî misalnya, mendefinisikan pengetahuan sebagai kehadiran jiwa pada makna sesuatu (wuṣ̂ul al-nafs ilâ ma'nâ shay') (Rosenthal 1970, 115). Sementara itu, al-Ghazâlî berpendapat bahwa pengetahuan adalah pengakuan akan hal itu (ma'rifat al-shay' 'alâ mâ huwa bihî) (Treiger 2002, 29). Menurut Ibn 'Arabî, pengetahuan adalah perolehan mental dari mengetahui apapun subjek dalam batas keberadaannya seperti apa (tahṣ̂l al-qalb amran mâ 'alâ haddi mâ huwa 'alayhi dhâlika al-amr). Artinya, pengetahuan adalah sifat yang dikaitkan dengan pikiran melalui akuisisi ini. Pikiran adalah pengenal, hal yang diketahui (Ibn 'Arabî 1972, 322).

Ibn 'Arabî menolak teori terkenal yang diajukan oleh para ahli logika yang mengatakan bahwa pengetahuan terdiri dari konsepsi mental (tasawwur) dan assent (tașlîq). Pengetahuan bukanlah representasi mental terhadap objek yang diketahui atau makna ( $m a$ 'nâ) yang pegang oleh 'tahu'. Sebab tidak semua hal yang diketahui bisa dibayangkan, dan tidak semua orang yang tahu mampu membentuk tidak masuk akal dalam pikirannya. Betapapun, konsepsi adalah alat pengenalnya imajinasi, pembentukan citra mental yang mewakili objek mengenalnya. Tapi representasi mental ini, menurut Ibn 'Arabî, tidak lain adalah persepsi (hâlat) pikiran yang sementara dipegang oleh bagian imajinasi imajiner, meskipun dia tidak melakukannya menyangkal adanya objek pengetahuan tertentu yang melampaui dan lolos dari pemahaman fantasi manusia. Sedangkan menurut al-Ghazâlî, pengetahuan itu tidak lain adalah kepastian (yaqîn) (Treiger 2002, 29). Adapun menurut Ibn 'Arabî, pengetahuan tidak dapat dihasilkan dari pertanyaan sederhana. Padahal, sejak dulu ada satu hal yang tersisa di dalamnya setelah pengupasan jejak sifat-sifatnya (salb athar alawșâf). Oleh karena itu, bisa dikatakan bahwa realitas pengetahuan terdiri dari epistemis dan ontik yang meliputi semua (alihhạtah 'alâ kulli wajh) (Chittick 1989, 147-148)

Berbagai pengertian ilmu tersebut menyimpulkan bahwa dalam epistemologi sufi, pengetahuan merupakan sesuatu yang bersumber dari kebenaran hakiki (Tuhan), dan untuk mencapai kebenaran hakiki harus melewati dimensi batin hingga batin terdalam. Pengetahuan akan datang 
melalui pembacaan dan pengalaman batin untuk mengenal Allah dan alam secara keseluruhan. Oleh sebab itu, fenomena alam merupakan cara untuk mengetahui hakikat Tuhan. Bahwa pengetahuan tentang Tuhan akan mengantarkan manusia untuk memahami segala sesuatu yang terjadi di dunia. Salah satu cara memahami Tuhan adalah dengan mengamati fenomena alam. Alam dengan segala fenomenanya bagi kaum sufi merupakan tajallî dari Tuhan dan kekuasaannya (Schimmel 1975, 71).

Tafsir sufi memberikan pengalaman tentang perjalanan hati yang dengannya manusia dapat 'melihat' dan langsung mengalami 'kebenaran'. Pengetahuan ini sering disebut dalam filsafat sebagai pengalaman religius (religious experiences). Dalam pengertian yang lebih luas, pengalaman religius juga mencakup pemahaman spiritual intuitif internal yang hanya diberi kepada orang yang percaya 'substansi' atau 'realitas' sesuatu (Chittick 1989, 8-11)

Mufasir sufi memahami ayat-ayat fenomena alam dengan cara yang berbeda dari kebanyakan mufasir lain. Dalam mendekati ayat, sufi selalu berorientasi kepada makna batin dan usaha untuk mendekatkan diri kepada Allah. Sedangkan mufasir lain hanya terhenti pada makna zahir dan kebahasaan (Maḥmûd 1987, 46) Tafsir sufi memahami ayat di atas bukan hanya bercerita tentang moral dan hubungan antara manusia dengan Penciptanya. Namun, Alquran juga berisi ayat tentang fenomena alam yang menantang manusia untuk berfikir bagaimana hubungan antara Tuhan, manusia, dan alam. Ayat-ayat tentang fenomena alam ini bertujuan untuk memperlihatkan eksistensi Tuhan dengan segala kekuatan dan kekuasaannya dalam mengatur harmoni antara relasi manusia dan alam. Oleh sebab itu, diperlukan analisis bagaimana tafsir sufi mendeskripsikan eksistensi Tuhan melalui fenomena alam, seperti gunung, sifat binatang, karakter wanita, dan lain-lain (Iwanebel 2014).

\section{Tafsir Sufi sebagai Kesadaran Manusia}

Masterson memahami keberadaan Tuhan melalui kesadaran manusia, sedangkan kesadaran manusia terkait dengan fenomena (Masterson 2013, 78). Masterson banyak terpengaruh dengan pemikiran fenomenologi yang diperkenalkan oleh E. Husserl. Fenomenologi aliran Husserl memang punya perhatian khusus pada kesadaran manusia, dan dalam kajian agama, kesadaran merupakan fokus dari pengalaman keagamaan. Mungkin karena inilah maka dalam kajian keislaman, 
pendekatan fenomenologis banyak dikembangkan oleh para sarjana yang mendalami tasawuf. Seorang orientalis asal Perancis bernama Henry Corbin (1903-1978) merupakan tokoh yang mula-mula menggunakan pendekatan fenomenologis dalam kajian Islam, ia menulis tentang Ibn 'Arabî. Corbin kemudian melanjutkan bahwa tujuan dari studi tentang Ibn al-Arabî bukanlah untuk membentangkan sejarah pemikiran dengan cara melacak asal usul dan mendaftar pengaruh-pengaruh, karena pendekatan semacam itu akan mengerdilkan tokoh yang tengah dikaji. Tokoh-tokoh semisal Ibn al-Arabî, Suhrawardî, Mulla Șadrâ dan lain sebagainya, kata Corbin, mengatakan bahwa ide tertentu yang mereka tulis tidak akan ditemukan di manapun, karena ia adalah temuan mereka sendiri melalui pengalaman pribadi (it is their discovery of their personal experience) (Corbin 1969).

Kesadaran manusia melalui pengalaman-pengalaman keagamaan (religious experiences) sebagaimana yang ditawarkan oleh Masterson, Husserl, dan Thomas Aquinas, pada esensinya sama seperti yang digagas oleh ulama Islam dalam paradigma fenomenologi yaitu Suhrawardî. Bedanya, Suhrawardî mencoba mendamaikan perdebatan dua paradigma, yakni rasional dan hati, yang mencoba memperebutkan peradaban Islam. Sedangkan Husserl mendamaikan antara orientasi rasional dan orientasi empiris yang berkembang di Eropa pada saat itu.

Konsepsi kesadaran manusia sebagai makhluk Tuhan sendiri banyak diimplementasikan oleh tokoh-tokoh sufi klasik. (Sands 2006). Walaupun tidak banyak yang bisa dicatat dari peneliti kajian keagamaan dari kalangan Muslim. Barangkali yang memadai untuk disebutkan di sini adalah Joachim Wach, Charles J. Adam dengan karyanya Islamic Religious Tradition, Sayyid Hossein Nasr yang mengarang sebuah buku di bidang fenomenologi yang berjudul Knowledge and The Sacred, Suhrawardi dengan Filsafat Iluminasi dan Fenomenologinya, juga Hasan Hanafi dengan Turâth wa Tajdîd dan Sachiko Murata dalam The Tao of Islam (Susilawati, 2015, 64).

Berdasarkan itu, interpretasi-interpretasi masa lampau yang memuat kesadaran tentang memberikan kesadaran historis dari pemikir klasik dapat dilanjutkan pada tahapan kesadaran eidetis dan praktis. Terdapat ratusan ayat tentang fenomena alam dalam Alquran yang memberitakan banyak hal mulai dari asal mula jagad raya, cahaya matahari, keseimbangan alam, gaya grafitasi bumi, dan lain sebagainya. Sebagaimana diketahui, kaum sufi selalu berorientasi untuk mencapai esensi Tuhan melalui kesadaran, termasuk ketika berhadapan dengan ayat-ayat fenomena alam. Tidak hanya 
itu, pilihan-pilihan ayat dalam penjelasan fenomena juga berbeda dengan pilihan ayat dalam tafsir ilmi atau tafsir eksoterik.

Kebanyakan para penafsir mengambil ayat-ayat tentang gejala alam sebagai fenomena alam dalam menjelaskan hubungan manusia dan Tuhan, seperti fenomena gunung, kejadian sungai, pohon, langit, dan lain sebagainya. Sedangkan tokoh sufi mengambil ranah batin terhadap fenomena alam dalam menjelaskan kesadaran akan Tuhan, seperti femininitas wanita, substansi petir, peran angin, konsep cahaya, simbolisasi matahari dan bulan, manifestasi pohon, dan lain-lain. Menurut argumen sufi, semua manifestasi di dunia disebabkan oleh interaksi unsur-unsur alam, yang bekerja dengan kekuatan mereka sendiri. Setiap sebab memiliki efeknya, dan efeknya lagi menjadi penyebab reaksi. Dengan demikian, alam bekerja dalam hirarki sebab akibat. Bahwa setiap penyebab pasti memiliki beberapa penyebab sebelumnya atau penyebab pertama untuk memproduksinya. Secara logis satu penyebab bisa menghasilkan banyak efek, efeknya lagi menjadi penyebab kedua, menghasilkan reaksi baru. Ketika pikiran intelektual mencari penyebab kedua, orang bijak hanya merasakan penyebab pertama. Udara, bumi, air, menjadi penyebab kedua yang disebut penyebab preseden membuat mereka bertindak dan berhenti sejenak dan tersembunyi (Chittick 1989, 89-90)

Terdapat beberapa pembacaan tentang fenomena alam dalam perspektif sufi. Pertama, penafsiran sufi tentang manifestasi pohon dalam Alquran. Alquran menyebutkan sebanyak 25 ayat tentang pohon (Q.S. alNaḥl [16]: 68, Q.S. al-Hajj [22]: 18, Q.S. al-Naml [27]: 60, Q.S. al-Raḥmân [55]: 6, dan Q.S. al-Wâqi'ah [58]: 52). Alquran memperkenalkan pohon sebagai makhluk atau entitas atau penghuni surga selain sungai (Q.S. Muhammad [47]: 15), perabotan (Q.S. al-Zukhruf [43]: 71), emas (Q.S. alInsân [76]: 15-16), dipan, bejana dari perak bantal-bantal, gelas, dan permadani (Q.S. al-Ghâshiyah [88]: 12-16), makanan surga seperti buah kurma dan delima (Q.S. al-Wâqi'ah [56]: 20-21). Penafsiran sufi atas fenomena pohon yang ada dalam Alquran tidak hanya berkaitan dengan manfaat dan peruntukan pohon sebagai ciptaan Allah bagi manusia (alAlûsî n.d., 508), akan tetapi lebih menyadari pohon sebagai sebuah entitas yang hidup serta hubungannya dengan Allah sebagai pencipta dan manusia sebagai entitas lain, sebagaimana terdapat dalam Q.S. Ibrâhîm [14]: 24-25. Para sufi menggambarkan seluruh alam semesta sebagai pohon yang mampu berbicara seperti yang dilakukan Ibn 'Arabi dalam kitabnya Shajarat al-Kawn (pohon kehidupan) (Ibn 'Arabî 2004, 143). Kemudian, diulas oleh 
William Chittik dalam The Sufi Path of Knowledge: Ibn al-Arabi's Metaphysics of Imagination bahwa sebuah pohon tempat manusia adalah buah terakhir yang paling berharga. Sufi merasakan bahwa kekuatan pohon sebagai entitas makhluk merupakan fenomena alam yang esensinya sama dengan pohon kehidupan. Pohon Kehidupan adalah konsep yang dikenal dari zaman kuno untuk pohon yang berakar di bumi dan mencapai langit sehingga menjadi suci seperti halnya manusia (Ibn 'Arabî 2004, 35).

Dalam Q.S. Ibrâhîm [14]: 25 dilanjutkan dengan informasi bahwa pohon sebagai sebuah fenomea alam terikat dengan eksistensi Tuhan dalam kata بادِنِ رَبَّها. Hal ini menunjukkan bahwa pohon sebagai prinsip kehidupan melambangkan kekuatan dan kebijaksanaan Tuhan. Buah yang dihasilkan pohon merupakan manifestasi Tuhan di dunia yang sejalan dengan sifat rahmân dan rahîm-Nya (Alibhai 1990, 30-32). Pada poin ini, Ibn 'Arabî menggugah kesadaran manusia akan keterikatannya dengan Tuhan sebagai pengatur kehidupan.

Bahkan Alquran menyebutkan nama pohon khusus di surga Firdaus sebagai taman abadi berisi pohon-pohon sangat khusus yang sangat membanggakan disebut dengan Tuba yang namanya dikembangkan dari ucapan 'Kebahagiaan'. Tuba adalah janji yang dipersonifikasikan dari kebahagiaan abadi yang orang harapkan di surga. Tokoh sufi lain seperti Bâyezîd Bistâmî, dalam penerawangan sufinya mengeluarkan istilah "pohon kesatuan" ketika memahami manifestasi pohon dalam Alquran. Sedangkan Abû al-Husayn al-Nûrî pada saat yang sama mengembangkan konsep "pohon esoteris ma'rifat." Dari semua pembacaan tokoh sufi terhadap manifestasi pohon dalam Alquran dapat disimpulkan bahwa pohon merupakan perpanjangan dari manifestasi Tuhan dalam sifat filliyah-Nya yaitu al-Rahîm. Jalâl al-Dîn al-Rûmî dalam Mathnawî Ma'nawî menggambarkan manifestasi pohon dalam Alquran sebagai "Setiap daun pohon, puji syukur Allah, hanya pikiran saleh yang bisa mendengar ucapan suci mereka" (Chittick 2005, 47).

Kedua, Alquran juga menyebut tentang fenomena petir dan guntur. Tokoh sufi seperti Ibn 'Arabî memandang petir dari perspektif esotericfenomenologinya dan guntur sebagai manifestasi kekuatan dan tanda-tanda Tuhan yang berapi-api. Alquran menyatakan bahwa "guntur memuji Dia" (wa yusabbih al-ra'd bihamdihi) (Q.S. al-Ra'd [13]: 13). Sedangkan untuk kilat, Ibn 'Arabî memaknainya sebagai manifestasi dari Zat Ilahi (Chittick 1989, 89). Oleh karena itu, kilat Ilahi dilambangkan dari masa-masa awal sebagai 
cahaya yang dapat menerangi walaupun dalam interval waktu yang sementara. Ini merupakan sebuah gagasan yang berasal dari bahasa surah alBaqarah ayat 20. Kilat dalam ayat ini dicitrakan sebagai manifestasi Tuhan dalam memberikan petunjuk bagi manusia. Menurut Ibn 'Arabî, berbicara tentang kilat berarti berbicara tentang cahaya. Karena kilat memiliki unsur cahaya yang digambarkan dalam Alquran sebagai konsep ketuhanan terbesar. "Tuhan adalah terang langit dan bumi" (Q.S. al-Nûr [24]: 35). Dengan demikian, dinyatakan bahwa Alquran menekankan berkali-kali bahwa Tuhan membimbing manusia dari kegelapan ke cahaya, al-žlumât ilâ al-nûr. Ibn 'Arabî mengalihkan daya interpretasinya dari fenomena kilat kepada konsep cahaya lalu menerangkan keterlibatan Tuhan sebagai empunya cahaya. Hal ini mengindikasikan bahwa Ibn 'Arabî berorientasi pada kesadaran akan wujud Tuhan dari partikel-partikel makhluk (Ibn 'Arabî 1968, 21).

Cahaya memainkan peran sentral dalam hampir semua tradisi keagamaan. Konsep cahaya yang dengan sendirinya terang-terangan terlihat dan dirasakan oleh mata manusia. Pada masa awal, para tokoh sufi yang menginterpretasikan Alquran percaya bahwa Nabi Muhammad memang dimaksudkan sebagai rongga yang digunakan oleh Allah sebagai bukti yang bercahaya dari cahaya Ilahi memancar melalui-Nya. Alquran menyebut Nabi Muhammad sebagai sirâj munîr "lampu yang bersinar" (Q.S. al-Ahzâb [33]: 46). Penafsiran ini banyak menyebar di kalangan umat Islam termasuk di Indonesia dengan paham "Nûr Muhammad" yang diintrodusir oleh sejumlah penganut sufi. Al-Jurjânî misalnya, walaupun seorang Ash'arî tidak menghalanginya untuk berpendapat tentang Nûr Muhammad. Menurutnya, Nûr Muhammad adalah awal yang ada dan dialah semuliamulia makhluk, dan karena dialah Allah menciptakan alam seluruhnya (tanpa dijelaskan alam dibuat dari nûrnya ataukah bukan") (al-Jurjânî 1983, 90). Begitupula al-Jillî memandang bahwa akal yang pertama (akal kreator) dinasabkan kepada Muhammad. Karenanya Allah menciptakan Jibril di waktu terdahulu. Maka Muhammad adalah asal dari seluruh alam semesta ini (al-Jillî n.d., 4). Jika faham Nûr Muhammad ini diteliti, maka akan sampai pada kesimpulan bahwa pemahaman ini diadopsi dari pemahaman filsafat Yunani (Platonisme), yaitu bahwa awal penciptaan itu adalah haba'/debu (atom) dan yang pertama-tama wujud adalah akal kreator atau akal fa'âl. Dari akal kreator ini tumbuh alam atas, langit-langit, kemudian alam bawah dan seterusnya (Zaydân 1998, 116-117) 
Literatur tafsir sufistik selalu memasukkan benda-benda alam seperti matahari, bulan, dan bintang sebagai bagian dari konsumsi kajian tentang cahaya. Semuanya merupakan perangkat dalam representasi cahaya Tuhan. Cahaya benda-benda alam merupakan instrumen dari hakikat cahaya yang sebenarnya, yaitu Tuhan. Dengan instrumen cahaya ini akan memberikan manfaat keharmonisan alam dan manfaat bagi manusia. Perubahan waktu antar musim yang tepat memberikan kebahagiaan dan keceriaan. Hujan menumbuhkan jagung, buah-buahan, dan bunga. Pergantian siang dan malam memberi kesempatan bagi manusia untuk bekerja dan beristirahat.

Sebagai simbol Tuhan, matahari memanifestasikan keagungan dan keindahan. Matahari menerangi dunia dan membuat buah menjadi matang. Akan tetapi, dibalik semua manfaatnya itu, matahari tidak dapat didekati dan akan menghancurkan semuanya dengan api. Seperti yang alRûmî katakan ketika memperingatkan muridnya untuk menghindari 'sinar matahari yang telanjang' (Chittick 2005, 59). Hal yang lebih penting bagi manusia selain matahari adalah bulan, tikar terang menunjukkan waktu. Bulan adalah simbol kecantikan dan untuk membandingkan kekasih tercinta dengan bulan yang bercahaya adalah pujian tertinggi yang bisa diberikan seseorang kepadanya. Perumpamaan bulan sebagai simbol kecantikan, baik untuk kata badr (bulan purnama) maupun hilâl (bulan sabit), bulan tetap melambangkan kesempurnaan. Sampai hari ini, umat Islam mengatakan sedikit doa atau syair saat mereka melihat bulan sabit untuk pertama kalinya. Pada kesempatan ini juga, mereka suka melihat orang yang cantik atau sesuatu yang terbuat dari emas dan mengucapkan berkat dengan harapan semoga bulan itu bisa indah. Diceritakan bahwa Sufi besar India, Nizâa al-Dîn Awliyâ, biasa meletakkan kepalanya di kaki ibunya saat bulan sabit muncul di langit karena penghormatan terhadap sang penerus dan ibu yang saleh (Gaborieau 2008, 192).

Sementara bulan adalah simbol keindahan manusia, itu juga bisa dianggap sebagai simbol kecantikan Ilahi yang tidak terjangkau yang tercermin di mana-mana. Bintang-bintang meskipun cahayanya tidak konstan, namun keberadaannya berfungsi sebagai tanda bagi umat manusia (Q.S. al-An'âm [6] :97). Mereka juga sujud di hadapan Tuhan, bintang dan pohon sujud keduanya (Q.S. al-Raḥmân [55]: 6). Pentingnya bintang sebagai lambang sufistik bisa dipahami dari awal surah al-Najm [53]. Bintang-bintang merupakan manifestasi Tuhan sebagai panduan untuk mendapatkan kepentingan navigasi dan astronomi yang terinspirasi di abadabad awal Islam. 
Ketiga, peran angin yang datang sebagai janji rahmat-Nya (Q.S. alA'râf [7]:57) karena angin menandakan kedatangan hujan. Angin lembut membawa tahta Sulaymân (Q.S. Saba' [34]:12), namun angin șarșar yang dingin menghancurkan kota-kota yang tidak taat dari 'Âd dan Thamûd (Q.S. al-Hâqqah [69]: 6). Dengan demikian, istilah șarșar menjadi tanda untuk kekuatan destruktif. Banyak penyair kemudian di dunia Persia bersumpah bahwa goresan pena mereka seperti șarsar untuk menghancurkan musuh pelindung mereka. Sementara yang lain dengan kurang sombong akan melihat dua aspek aktivitas Tuhan sebagai manifestasi kebaikan dan kecantikan kemurahan hati, dan keagungan dan kemuliaan jalanku dalam dua aspek angin yang menghancurkan orangorang kafir namun merupakan pelayan yang rendah hati kepada nabi Sulaymân. Salah satu aspek dari angin yang ramah adalah angin selatan atau timur yang disebut nafas al-Raḥmân (nafas Yang Maha Penyayang), yang sampai kepada Nabi dari Yaman membawa keharuman kesalehan Uways alQarnî karena sebelumnya angin sepoi membawa aroma penyembuhan kemeja Yûsuf kepada ayahnya yang buta, yakni Ya'qûb (Q.S. Yûsuf [12]: 94).

Ketiga fenomena alam di atas dalam tafsir sufi dilambangkan sebagai bentuk kesadaran manusia atas manifestasi Tuhan bagi sekalian makhluknya. Seluruh penciptaan, baik dunia materi maupun alam adalah bukti terbaik, paling jelas dan paling universal untuk mencapai hakikat Tuhan. Jelas bahwa sinar keabadian-Nya memberikan kehidupan dan harapan pada semua makhluk, dan bahwa semua ciptaan mendapatkan keuntungan, baik eksistensinya maupun kemajuannya dari-Nya. Memahami manifestasi Tuhan dalam kosmik merupakan kajian dalam perspektif transendental, Tuhan itu berjarak dari hambanya. Ia Maha Tidak Dikenal dan tidak dapat dipahami karena Kemahaagungan-Nya. Namun dari sudut pandang imanensi, Tuhan menunjukkan diri-Nya dalam segala hal sesuatu dan dapat dialami melalui segala sesuatu yang tampak dan dirasakan. Seluruh kosmos dan segala sesuatu yang ada di dalamnya merupakan pengungkapan diri Tuhan.

Konsep kesadaran manusia yang diperkenalkan oleh Ibn 'Arabî sangat berpengaruh kepada pemikiran tasawuf berikutnya. Seperti pemikiran Sachiko Murata tentang gambaran Tuhan sebagai entitas transendental yang menampakkan dirinya melalui keseimbangan kosmik, karena adanya saling ketertarikan antara jiwa yang cenderung pada sifat badani dan ruh yang memiliki sifat ilâhiyat. Hal ini sangat menarik karena 
Murata selalu menghubungkan realitas Tuhan dengan dimensi batin seperti yang dan yin (sifat-sifat maskulin dan feminin). Menurutnya, dimensi batin manusia mampu mengaktualisasikan peranan ilâhiyat sebagai yang memberikan perintah kebaikan dan petunjuk akan selalu memberikan teguran kepada jiwa-jiwa yang lalai untuk selalu mengingatkan jiwa agar menghadap kembali pada ruh dan siap menerima kebaikan. Inilah yang dikatakan Murata sebagai jiwa yang sehat, yakni jiwa yang sangat dipengaruhi oleh ruh atau kebaikan. Jadi, jiwa yang sehat akan terlihat dari perilaku manusia yang bisa menjalin hubungan yang baik dengan sesama manusia dan hubungan baik dengan Tuhan (Murata 1992, 299).

Dari penjelasan di atas, dapat disimpulkan bahwa kesadaran tringulitas yang saling berhubungan dalam tafsir sufi dapat digambarkan seperti yang ada pada gambar 1 .

Gambar 1

Kesadaran Tringulitas

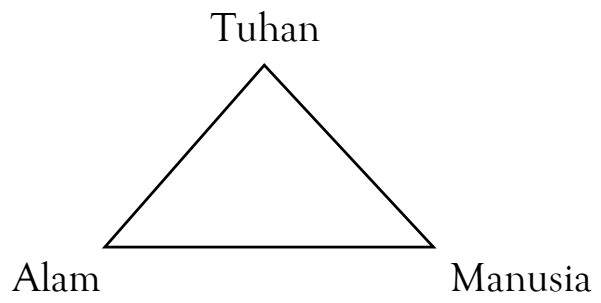

\section{Penafsiran Metafisis tentang Tuhan}

Masterson menjelaskan perlunya pendekatan lain selain fenomenologi untuk menjelaskan keberadaan individu independen tersebut (Tuhan) dan lebih khususnya transendensi Tuhan. Pendekatan lain yang dibutuhkan adalah pendekatan metafisik dan teologis. Keduanya ada dalam wilayah sufistik. Dengan metafisika, Masterson memahami metafisika realis, sebagaimana Masterson memahaminya sebagai "realisme metafisis." Ia memahami bahwa dunia nyata eksis secara independen dari representasi kita. Realisme metafisis mencari sejauh mungkin dan mencari catatan impersonal objektif tentang penilaian tentang hakikat sesuatu (Masterson 2013, 34). Menurutnya, Thomas Aquinas telah berhasil menghadirkan bukti aposteriori tentang keberadaan Tuhan. Bukti-bukti metafisik yang sah didasarkan pada prinsip non-kontradiksi. Bukti-bukti seperti itu dimulai 
dengan keadaan makhluk-makhluk terbatas yang tampaknya bertentangan dan menunjukkan bahwa tanpa penegasan dari penyebab penjelasan di luar makhluk-makhluk yang terbatas, kontradiksi-kontradiksi seperti itu tidak dapat diselesaikan.

Dalam tradisi intelektual sufi, berbicara tentang kosmos (alam) sama artinya dengan berbicara tentang Tuhan (Siraj 2014). Dalam kajian ilmiah, hakikat Tuhan memerlukan berbagai pendekatan dan perspektif. Menurut perspektif esoterik-fenomenologi, memahami hakikat Tuhan berarti mengeksplorasi cara-cara di mana fenomenologi, metafisika, dan penyelidikan teologis untuk menjelaskan satu sama lain. Ini merupakan masalah yang sangat menarik dan penting bagi masa depan teologi filosofis dan filsafat agama. Mendekati Tuhan pada dasarnya memberikan dialog tentang isu-isu teologis dan teistik antara tiga pendekatan, yaitu fenomenologis, metafisika, dan teologi. Ketiganya merupakan termasuk dalam ranah kajian ilmu sufistik Islam.

Salah satu karya yang menjelaskan fenomena Tuhan dari tiga perspektif adalah karya tulis Masterson yang berjudul Approaching God Between Phenomenology and Theology (Masterson 2013, 69). Ia membagi karyanya dalam tiga bab dengan tiga pendekatan dalam menjelaskan fenomena Tuhan. Tiga pendekatan tersebut adalah pendekatan fenomenologis, metafisik, dan teologis. Masing-masing dilihat sebagai instrumen dari prinsip pertama. Prinsip pertama yang komprehensif harus mengikuti 'kesadaran manusia' dalam kasus fenomenologi; 'keberadaan' dalam kasus metafisika; dan 'Tuhan' dalam kasus teologi. Masterson menyatakan bahwa ketiga pendekatan diperlukan dalam upaya untuk berbicara secara tepat tentang Tuhan. Mereka tidak dapat direduksi tetapi saling melengkapi (Masterson 2013, 3).

Masterson menjelaskan tentang manfaat pendekatan fenomenologis yang menekankan perhatian terhadap pengalaman pribadi, perlawanannya terhadap setiap pertanyaan memohon reduksionisme, dan keterbukaan terhadap fenomena agama. Namun menurut Masterson, fenomenologi memiliki keterbatasan ketika menjelaskan tentang realitas Tuhan. Terkait dengan ini, ia memberikan beberapa argumentasi. Pertama, fenomenologi acapkali mereduksi dan mendistorsi sifat-sifat alami agama. Kedua, fenomenologi membatasi uraian tentang Tuhan terhadap apa yang ada dalam pengalaman manusia, sementara keyakinan orang beragama tentang transendensi ilahi melibatkan klaim bahwa Allah tidak dibatasi oleh pengalaman manusia (Masterson 2013, 21). 
Menurut kajian sufi, sebuah realitas tidak akan ada manfaatnya kecuali dirasakan dalam bentuk pengalaman dan eksperimen (Lobel 2000, 90). Termasuk realitas ibadah, banyak pertanyaan yang muncul tentang alasan mengapa harus menyembah Tuhan, dan apakah pengetahuan teoretis tentang hukum-hukum-Nya tidak cukup? Untuk realisasi tertinggi jawabannya adalah tidak. Pengetahuan teoretis suatu subjek tidak pernah bisa menggantikan pengalaman yang perlu direalisasikan. Teori Tuhan tidak bisa menjelaskan memberikan sukacita dan kedamaian yang lengkap. Maka Tuhan harus benar-benar disadari atau mencapai keadaan kesadaran yang memberikan kebahagiaan kekal melalui zikir dan pemujaan terhadap keindahan alam dan sumbernya, yaitu Tuhan. Oleh sebab itu, penafsiran sufi konsen terhadap pemaknaan yang mengarah kepada pengalaman batin tentang fenomena alam.

Dalam pandangan sufistik, Tuhan merupakan sebuah hakikat yang berada. Menurut Ibn 'Arabî yang merupakan pencetus paham waḥdat alwujûd (Rofi'ie 2010), Tuhan merupakan realitas yang berbeda dengan alam. Sedangkan mata, indera, dan akal merupakan bagian dari alam. Oleh sebab itu, tidak mungkin mengetahui Tuhan dengan sarana-sarana tersebut. Untuk mengetahui realitas Tuhan, manusia sebagai subjek harus mendekatinya dengan satu-satunya sarana yang dapat mengantarkan dirinya kepada Tuhan, yaitu batin-intuitif dengan tahapan-tahapan pengalamannya. Manusia sebagai subjek harus mengaktualisasikan bentuk Tuhan dengan memanifestasikan nama-nama Tuhan dalam diri manusia yang masih bersifat potensi tersebut.

Dengan demikian, manusia tidak akan dapat mencapai hakikat Tuhan kecuali dengan memanifestasikan nama nama Tuhan dalam diri manusia dengan melakukan proses penyucian diri atau yang disebut dengan takhalluq bi alilâh (Corbin 1969). Proses tersebut diistilahkan oleh Ibn 'Arabî dengan tajallî (penampakan diri al-Haqq), atau al-Fayḍ. Kondisi tajallî ini terbagi dua, yakni tajallî bi al-quwwah dan tajallî bi al-fííl. Tajallî bi alquwwah baru berada di wilayah akal dan kesadaran. Subjek belum dapat menyaksikan (mushâhadah) wujud-wujud emanasi Tuhan dalam alam yang dapat dilihat ('Alam al-Shuhûd). Pada titik ini, hakikat tentang Tuhan tidak hanya hadir dalam kesadaran diri, tetapi juga hadir melalui fenomenafenomena alam (Chittick 1989)

Oleh sebab itu, dapat disimpulkan, baik dalam perspektif esoterik maupun pandangan fenomenologi, hakikat Tuhan hanya bisa diketahui 
dengan pengalaman spiritual. Bedanya adalah, menurut pandangan sufistik, hakikat Tuhan hanya dapat diketahui melalui sarana intuitif. Sedangkan menurut pandangan fenomenologis, hakikat Tuhan dapat diketahui melalui pengalaman dari sebuah kesadaran (being exp). Sebagai hasilnya, keduanya melihat berbagai fenomena alam dapat menjadi manifestasi Tuhan di dunia (Knysh 2010). Bagaimana pertemuan antara pandangan sufistik dan fenomenologi dalam memandang Tuhan dapat dijelaskan melalui gambar 2 .

Gambar 2

Pandangan sufistik dan fenomenologi dalam melihat Tuhan

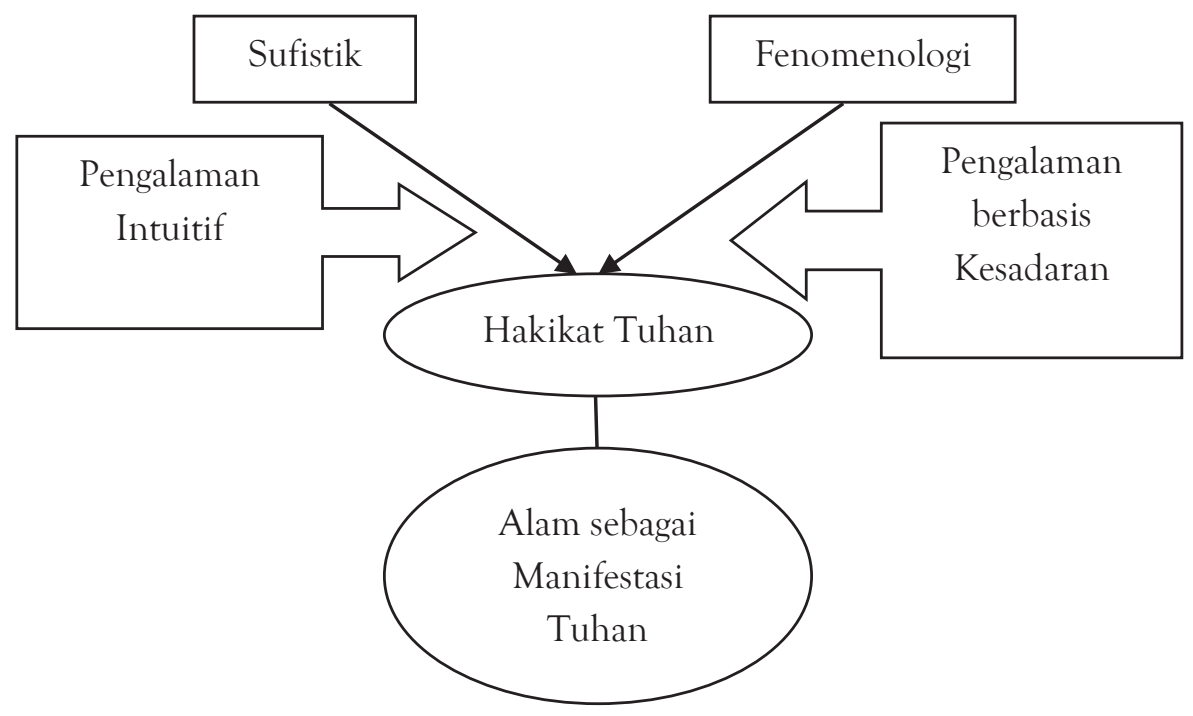

Dalam sufistik dan fenomenologi, semua benda punya pancaran gejala-gejalanya sendiri-sendiri. Seseorang akan bisa lebih memahami benda tersebut apabila ia menganggap benda sebagai subjek yang menceritakan diri sendiri melalui gejala-gejala yang memancar darinya.

Dengan metafisika, Masterson memahami metafisika realis; dan seperti yang dicontohkan Marionologi, Aquinas mencontohkan metafisika semacam itu. Sebagaimana Masterson memahaminya dengan realisme metafisik, ia menerima bahwa dunia nyata eksis secara independen dari representasi kita, mencari sejauh mungkin secara manusiawi untuk memberikan catatan impersonal objektif dalam penilaian yang berusaha lebih atau kurang berhasil untuk menyesuaikan diri dengan itu (Masterson 
2013, 34). Masterson memberikan perhatian khusus di sini untuk konsep analogis menjadi: "seseorang bahkan dapat berbicara tentang 'reuction metafisik' atau 'memimpin kembali ke' kesatuan analogis keberadaan” (Masterson 2013, 35).

Catatan Masterson tentang Aquinas jelas, informatif, dan mencerahkan. Secara khusus ia menunjukkan bagaimana Aquinas mengatasi batas hylemorphism Aristoteles. Sedang untuk Aquinas pada dasarnya terbatas, dan ini tidak begitu karena pembatasan yang dikenakan oleh makhluk lain, tetapi karena keterbatasan intrinsik semua makhluk. Semua makhluk adalah komposit dan sifat dari komposisi tersebut adalah terbatas, penentuan terbatas. Keberadaan, esse, di sisi lain, menandakan tindakan bukan bentuk, yang mengaktualisasikan potensi karena ini adalah contoh khusus. Tuhan adalah esensi murni, eksistensi murni, tindakan wujud murni. Sementara esensi berkorelasi dengan intelek, keberadaan, tidak. Tuhan berada di luar pemahaman, karena Tuhan tidak ada. Act adalah "dasar dari semua kemungkinan, dari semua perubahan, atau semua kesempurnaan” (Masterson 2013, 50). Apa yang Aquinas hadirkan adalah bukti-bukti aposteriori tentang keberadaan Allah. Bukti-bukti metafisik yang sah didasarkan pada prinsip non-kontradiksi. Bukti-bukti seperti itu dimulai dengan keadaan makhluk-makhluk terbatas yang tampaknya bertentangan dan menunjukkan bahwa tanpa penegasan penyebab penjelasan di luar makhluk-makhluk yang terbatas, kontradiksi-kontradiksi semacam itu tidak dapat diselesaikan.

Pertanyaan tentang koeksistensi Allah dengan ciptaan-Nya, yaitu kesesuaian kebebasan manusia dan kemahatahuan dan kemahakuasaan ilahi, adalah klaim Masterson yang melatih kita hari ini lebih dari pertanyaan tradisional lainnya mengenai makna dan keberadaan Allah. Dalam menjawab pertanyaan ini, Masterson sekali lagi menekankan penekanan thomistic pada eksistensi (Sokolowski 2014, 603-605). Apa yang berbeda tentang penciptaan sebagai bentuk kausalitas adalah "bahwa itu adalah asal muasal supra-temporal mutlak eksistensi yang terbatas, esse, dan bukan proses temporal" (Masterson 2013, 62). Masterson menekankan bahwa akun semacam itu menandai jeda yang jelas dengan catatan Aristotelian tentang Tuhan sebagai penyebab akhir, dan bahwa terlepas dari klaim oleh "beberapa fenomenologis", untuk sebaliknya, Aquinas tidak mereproduksi Aristoteles dengan Tuhan sebagai mahluk tertinggi. Dengan kata lain, Aquinas bukan seorang teolog (Masterson 2013, 67). 
Kontribusi paling signifikan dan original dalam konsep Masterson adalah pemulihan peran kausalitas dalam studi agama dan teologi. Dalam perlakuannya terhadap metafisika, ia menunjukkan bahwa akal manusia mencari sebab-sebab, dan kausalitas itu membuat kesadaran manusia terlibat dalam realitas. Hal ini terjadi karena akal mencari sendiri fenomena kausalitas sebuah fenomena. Kesadaran manusia akan Tuhan merupakan fenomena, bukan melalui proyeksi, tetapi karena sesuatu meletakkannya di sana (Masterson 2013, 150).

Pada titik ini, tawaran Masterson sesungguhnya telah mengakomodir dimensi esoterik dan eksoterik secara bersamaan. Hal yang sulit dilakukan oleh kebanyakan pakar teologi. Tawaran cara fikir ini mungkin bisa menggambarkan dan menguraikan bagaimana para sufi menjelaskan entitas metafisika Tuhan dengan pendekatan-pendekatan kejadian dan fenomena alam.

Tawaran Masterson telah juga memenuhi tiga persoalan pokok yang terkait dengan epistemologi, yakni pertama, sumber pengetahuan itu dan cara mengetahuinya; kedua, sifat dasar pengetahuan (empiris, rasionalis, atau intuisi); dan ketiga, kebenaran (validitas) pengetahuan. Melalui argumentasi Masterson dapat disimpulkan bahwa sumber pengetahuan tentang Tuhan dapat diketahui melalui fenomena alam yang berprinsip pada 3 (tiga) hal, yakni kesadaran, teologi, dan metafisika. Sedangkan sifat dasar pengetahuan berbasis pada aspek empiris (religious experiences), rasio, dan kelembagaan hati (intuisi). Semua itu dapat diukur validitas kebenaran dan kesalahannya, karena fenomologi berpijak pada konsep realitas, teologi pada konsep rasio, dan intuisi berpijak pada konsep kesadaran manusia sebagai makhluk Tuhan.

\section{Simpulan}

Konsepsi esoterik-fenomenologi dalam pandangan Patrick Masterson adalah sumbangan untuk perdebatan mengenai pertanyaan meta-fenomenologis dan meta-teologis tentang cara pendekatan ke dan dari Tuhan. Bagi Masterson, tidak ada jawaban rapi untuk pertanyaan tentang hubungan fenomenologi, metafisika, dan teologi. Perpotongan ketiga pendekatan ini perlu terus dinegosiasikan. Masterson melihat dirinya menetapkan "peta jalan" untuk "lanskap kompleks." Pada saat yang sama, konsepsi itu sebenarnya sudah diaplikasikan dalam penafsiran tokoh-tokoh sufi seperti Ibn 'Arabî, al-Ghazâlî, dan lain sebagainya. 
Konsep pendekatan esoterik-fenomenologi Masterson dibentuk atas tiga aspek, yaitu kesadaran manusia, keberadaan, dan teologi Tuhan. Konsep ini terwujud dalam bentuk penafsiran sufi. Pertama, pada aspek kesadaran manusia, penafsiran sufi berorientasi pada kesadaran tringulitas yang saling berhubungan antara Tuhan, manusia dan alam. Hal ini dapat dilihat dari penafsiran Ibn 'Arabî tentang manifestasi pohon (Q.S. al-Nạ̣l [16]: 68, Q.S. al-Hajj [22]: 18, Q.S. al-Naml [27]: 60, Q.S. al-Raḥman [55]: 6, dan Q.S. al-Wâqi'ah [58]: 52), fenomena kilat dan guntur (Q.S. al-Ra'd [13]: 13), dan peran angin (Q.S. al-A'râf [7]:57). Kesadaran bahwa alam merupakan manifestasi Tuhan dan fenomena alam merupakan wujud yang terkasih dari Tuhan. Dunia materi dan alam, yang dipahami sebagai keseluruhan yang diciptakan, adalah bukti terbaik, paling jelas dan paling universal dalam hal keberadaan Tuhan.

Pada aspek keberadaan metafisis Tuhan, pendekatan esoterikfenomenologi memberikan gagasan dalam pengalaman empiris. Sedangkan dalam tafsir sufi, keberadaan metafisis Tuhan termanifestasikan dalam nama-nama Tuhan dalam diri manusia dengan melakukan proses penyucian diri atau yang disebut dengan takhalluq bi alilâh. Sementara itu, menurut pandangan fenomenologis, hakikat Tuhan dapat diketahui melalui pengalaman dari sebuah kesadaran (being exp). Sebagai hasilnya, keduanya melihat berbagai fenomena alam dapat menjadi manifestasi Tuhan di dunia.

Kontribusi paling signifikan dan original dalam konsep Masterson adalah pemulihan peran kausalitas dalam studi agama dan teologi. Dalam perlakuannya terhadap metafisika, ia menunjukkan bahwa akal manusia mencari sebab-sebab, dan kausalitas itu membuat kesadaran manusia terlibat dalam realitas. Hal ini terjadi karena akal mencari sendiri fenomena kausalitas sebuah fenomena. Kesadaran manusia akan Tuhan merupakan fenomena, bukan melalui proyeksi, tetapi karena sesuatu meletakkannya di sana. Pemikiran inilah merupakan sebuah pendekatan baru yang mampu mengakomodir dimensi esoterik dan eksoterik secara bersamaan. Dengan demikian, penulis menilai hal ini layak digunakan untuk memahami epistemologi sufistik, khususnya yang berkaitan dengan fenomena alam. 


\section{Daftar Pustaka}

Abu-Sway, Mustafa Mahmoud. 1994. "The Development in al-Ghazālì's Epistemology.” Journal Intellectual Discourse 2(2): 167-76.

Alibhai, Shams. 1990. "The Shajarat Al-Kawn Attributed to Ibn 'Arabī: an Analytical Study.” Tesis. McGill University.

al-Alûsî. n.d.. Rûh al-Ma'ânî. Lebanon: Muniriyyah.

Al-Walid, Kholid. 2018. "Takwil Epistemologis Ibn Sînâ atas Surah al-Nûr Ayat 35." Ulul Albab: Jurnal Studi Islam 19(1): 1-24.

Arif, Syamsuddin. 2002. "Sufi Epistemology: Ibn "Arabi on Knowledge ('Ilm).” Afkar: Jurnal Akidah E Pemikiran Islam 3(1): 81-94.

Al-Attas, Syed Muhammad Naquib. 2005. "Islamic Philosophy: An Introduction." Journal of Islamic Philosophy 1(1): 11-43.

Chittick, William C. 1989. The Sufi Path of Knowledge: Ibn al-Arabi's Metaphysics of Imagination. Albany: University of New York Press.

Chittick, William C. 2005. The Sufi Doctrine of Rumi. Bloomington: World Wisdom.

Corbin, Henry. 1969. Creative Imagination in the Sufism of Ibn Arabi. Terj. Ralph Manhem. Princeton: Princeton University Press.

al-Dhahabî, Muḥammad Husayn. 2004. Al-Tafsîr wa al-Mufassirûn, Vol. 2. Beirut: Maktabah Muṣaab ibn 'Amr al-Islâmiyah.

Gaborieau, Marc. 2008. The City in The Islamic World, Vol. 1. Leiden: Brill.

Ibn 'Arabî. 2004. The "Tree of Being": An Ode to the Perfect Man. Terj. Tosun Bayrak. London: Archetype.

Ibn 'Arabî. 1972. Al-Futûhât al-Makkiyyah. Kairo: al-Hay'at al-Miṣriyya talAmmah li al-Kitâb.

Ibn 'Arabî. 1968. Tafsîr al-Qur'ân al-Karîm, Vol. 1. Beirut: Dâr Yaqzat al'Arabiyah.

Iqbal, Sir Muhammad. 1934. The Recontruction of Religious Thought in Islam. London: University Press. 
Iwanebel, Fejrian Yazdajird. 2014. "Paradigma dan Aktualisasi Interpretasi dalam Pemikiran Muhammad al-Ghazālī.” Hunafa: Jurnal Studia Islamika 11(1): 1-22.

al-Jâbirî, Muhammad 'Âbid. 2009. Al-Bunyat al-Aql al-Arabî. Beirut: Markaz Dirâsat al-Waḥdat al'Arabiyyah.

al-Jillî, 'Abd al-Karîm ibn Ibrâhîm. n.d. Al-Insân al-Kâmil fì Ma'rifat alAwâkhir wa al-Awâil, Vol. 2. Lebanon: Dâr al-Fikr.

al-Jurjânî, 'Alî ibn Muhammad ibn 'Alî al-Zayn al-Sharîf. 1983. Kitâb alTa'rîfât. Beirut: Dâr al-Kutub al-'Ilmiyah.

Knysh, Alexander. 2010. Islamic Mysticism: A Short History. London: Brill.

Lobel, Diana. 2000. Between Mysticism and Philosophy: Sufi Language of Religious Experience in Judah Levi Kuzari. Albany: University of New York Press.

M. Anwar Syarifuddin. 2004. "Menimbang Otoritas Sufi dalam Menafsirkan al-Qur'an." Jurnal Studi Agama dan Masyarakat 1 (2): 1-18.

Maḥmûd, 'Abd al-Halîm. 1987. Manâhij al-Mufassirîn. Kairo: Dâr al-Katîb.

Masterson, Patrick. 2013. Approaching God: Between Phenomenology and Theology. London: Bloomburry.

Murata, Sachiko. 1992. The Tao of Islam, A Source Book on Gender Relationships in Islamic Thought. Albany: State University of New York Press.

Nur, Syaifan. 2012. "Epistemologi Sufi dan Tanggungjawab Ilmiah.” Kanz Philosophia 2(1): 135-51.

Rofi'ie, Abd Halim. 2010. "Wahdat al Wujud dalam Pemikiran Ibnu Arabi." Ulul Albab: Jurnal Studi Islam 11(2): 131-41.

Rosenthal, Franz. 1970. Knowledge Triumphant: The Concept of Knowledge in Medieval Islam. London: E. J Brill.

Sands, Kristin Zahra. 2006. Sufi Commentaries on the Qur'an in Classical Islam. London: Routledge.

Schimmel, Annemarie. 1975. Mystical Dimension of Islam. Carolina: University of North Carolina Press. 
Schimmel, Annemarie. 1994. Deciphering the Signs of God: A Phenomenological Approach to Islam. Albany: State Universityof New York Press.

Sokolowski, Robert. 2014. "The Relation of Phenomenology and Thomistic Metaphysics to Religion: A Study of Patrick Masterson's "Approaching God: Between Phenomenology And Theology." The Review of Metaphysics 67(3): 603-26.

Siraj, Fuad Mahbub. 2014. "Tasauf dan Kosmologi." Ilmu Ushuluddin 2(1): 53-68.

Susilawati, Erni. 2015. "Psikologi Sufistik (Studi atas Pemikiran Sachiko Murata dalam Buku The Tao of Islam)." Al-Banjari: Jurnal Ilmiah IlmuIlmu Keislaman 14(1): 60-75.

Treiger, Alexander. 2002. Inspired Knowledge in Islamic Thought: Al-Ghazali's Theory of Mystical Cognation and its avicennian Foundation. London: Routledge.

Yunus, Badruzzaman M. 2017. "Pendekatan Sufistik dalam Menafsirkan alQur'an.” Syifa al-Qulub: Jurnal Studi Psikoterapi Sufistik 2(1): 1-12.

Zaydân, Yûsuf. 1998. Al-Fikr al-Sûfî. Mesir: Dâr al-Amîn. 